\title{
Isparta ve Karaman illerinde elma üretim maliyetinin karşılaştırılması
}

\author{
The comparison of apple production costs in Isparta and Karaman provinces
}

\author{
Alamettin BAYAV ${ }^{1} \mathcal{A}$ (D), Bahri KARLI \\ ${ }^{1}$ Universtiy of Isparta Applied Sciences, Faculty of Agriculture, Department of Agricultural Economics, Isparta, Turkey.
}

MAKALE BILGISI / ARTICLE INFO

Makale tarihçesi / Article history:

DOI: $\underline{10.37908 / m k u t b d .687080}$

Geliş tarihi /Received:10.02.2020

Kabul tarihi/Accepted:28.05.2020

\section{Keywords:}

Apple, Single product budget analysis, Production cost, Isparta, Karaman

\footnotetext{
Corresponding author: Alamettin BAYAV $\triangle$ : alamettinbayav@hotmail.com
}

\section{ÖZET / A BSTR A C T}

Atıf / Citation: Bayav A, Karlı B (2020) Isparta ve Karaman illerinde elma üretim maliyetinin karssılaştırılması. MKU. Tar. Bil. Derg. 25(2) : 225-236. DOI: $10.37908 /$ mkutbd.687080

\section{GiRiş}

İnsan beslenmesiyle doğrudan ilgili olması nedeniyle tarım, tüm ülkeler açısından önemli bir sektör konumundadır. Özellikle, Türkiye gibi gelişmekte olan ülkelerde tarım önemli bir istihdam kaynağı ve milli gelirin önemli bir bileşeni konumundadır. Meyvecilik; dengeli beslenmeye katkı sağlama, tarıma dayalı sanayiye hammadde temin etme, istihdam oluşturma, milli gelir ve ihracat açısından tarım sektörü içinde önemli bir alt sektördür.
Türkiye, meyve üreten önemli ülkelerden biridir. 2017 yılında 865.590.060 ton olan dünya meyve üretiminin \%2,67'lik kısmını Türkiye karşılamıştır. Bu üretim payı ile Türkiye, Çin, Hindistan, Brezilya ve ABD'nin ardından beşinci sırada yer almaktadır (Anonim, 2020a). 2019 yılında Türkiye meyve üretimi, 26.226.027 ton olarak gerçekleşmiş olup, bunun \%13,8'lik kısmını (3.618.752 ton) elma üretimi oluşturmuştur (Anonim, 2020b). Elma dünya üzerinde çok geniş bir yayılım göstermekte ve dünyanın hemen hemen her yerinde yetiştirilebilmektedir. Çoğunlukla taze olarak tüketilmekle birlikte; meyve suyu, dondurma, pasta, 
marmelat vb. şekilde de tüketilebilmektedir. Dünyada en fazla elma üreten ilk on ülke sırasıyla Çin $(\% 49,8)$, ABD $(\% 6,2)$, Türkiye $(\% 3,7)$, Polonya $(\% 2,9)$, Hindistan $(\% 2,7)$, İan $(\% 2,5)$, İtalya $(\% 2,3)$, Şili $(\% 2,1)$, Fransa $(\% 2,1)$ ve Rusya (\%2)'dır (Anonim, 2020a). Türkiye'de hemen hemen her bölgede elma yetiştiriciliği yapılmaktadır. En fazla üretimin yapıldığı Isparta, Karaman, Niğde ve Antalya illeri; 3.618.752 ton olan 2019 yılı Türkiye üretiminin \%53,1'ini gerçekleştirmiştir. Araştırma kapsamındaki Isparta ilinde 732.036 ton, Karaman ilinde ise 485.363 ton elma üretimi gerçekleştirilmiştir (Anonim, 2020b).

Tüm ekonomik faaliyetlerde olduğu gibi tarımsal faaliyetlerde de işletmelerin temel amacı, işletmenin sürekliliğini sağlayacak karı elde etmektir. Bu amaca ulaşmak için üretim maliyetlerinin bilinmesi ön şartlardan biridir. Üretim maliyetlerinin bilinmesi birçok açıdan önemlidir. Özellikle üreticilerin orta ve uzun vadede üretim planlarını yapabilmeleri için maliyetlerin bilinmesine intiyaç vardır. Bir diğer önemli husus ise politika yapıcılara yol gösterici olmasıdır. Bilhassa fiyat ve destekleme politikalarında üretim maliyetlerinin bilinmesi önem arz etmektedir (Demircan ve ark., 2005). Elma üretiminin teknik yönleri birçok çalışmada ele alınmasına rağmen, ekonomik yönleri hakkında yapılan çalışmalar çok fazla değildir. Son yıllarda farklı ülkelerde elma üretiminin ekonomik yönü ve elma yatırımının karlılığı hakkında çalışmalar yapılmıştır (Ergün ve ark., 1984; Oğuz, 1997; Akcay ve ark., 1999; Glover ve ark., 2002; Karamürsel ve ark., 2004; Bruille ve Barritt, 2005; Demircan ve ark., 2005; Gül ve Onur, 2005; Uzunöz ve Akçay, 2006; Bayav ve Armağan, 2008; Bayramoğlu ve ark., 2009; Aydoğmuş ve Yılmaz, 2010; Malik, 2013; Piyush ve ark., 2013; Robinson ve ark., 2013; Zbanca ve Negritu, 2013; Badui ve ark., 2015; Uçar ve ark., 2016; Kanat ve ark., 2017; Wani, 2017). Ancak tüm bu çalışmalara rağmen yerel düzeyde ekonomik yönlerin ele alındığı çalışmalara ihtiyaç vardır (Uçar ve ark., 2016).

Bu çalışma, elma üretiminin yoğun olarak yapıldığı ve Türkiye üretiminde önemli bir yere sahip olan illerde (Isparta ve Karaman) gerçekleştirilmiş ve elma yetiştiriciliğinin ekonomik yönü karşılaştırmalı olarak ortaya koyulmuştur.

\section{MATERYAL ve YÖNTEM}

\section{Materyal}

$\mathrm{Bu}$ çalışmanın ana materyalini, Isparta (Eğirdir, Gelendost ve Senirkent ilçeleri) ve Karaman (Merkez ilçe) illerindeki elma üreticileri ile yüz yüze görüşme yapılarak elde edilen birincil veriler oluşturmuştur. Çalışmanın ikincil verileri ise Türkiye İstatistik Kurumu (TÜiK), Dünya Gıda ve Tarım Örgütü (FAO), T.C. Tarım ve Orman Bakanlığı il Müdürlüklerinden temin edilmiştir. Ayrıca, konu ile ilgili olarak daha önce yapılmış araştırma ve inceleme sonuçlarından da yararlanılmıştır.

\section{Yöntem}

Araştırmada kullanılan birincil verilerin elde edildiği işletmelerin belirlenmesinde, TUiK verileri esas alınmış ve Türkiye elma üretiminin yaklaşık \%33,6'sını karşılayan Isparta ve Karaman illeri araştırma kapsamını oluşturmuştur. il Tarım ve Orman Müdürlüklerinin görüşleri doğrultusunda gayeli örnekleme yöntemine göre Isparta ilinden, Eğirdir, Gelendost ve Senirkent ilçeleri; Karaman ilinden ise Merkez ilçe seçilmiştir. Belirlenen bu yerlerdeki işletmeler, çalışmanın anakitlesini oluşturmuştur. Örnekleme hacminin tespitinde, arazi genişliği kriteri dikkate alınmıştır. Bunun için belirlenen ilçelerde, 2017 yılı üretim sezonunda Çiftçi Kayıt Sistemine kayıtlı ve elma üretim alanı 5 dekar ve üstü olan işletmeler popülasyonu oluşturmuştur. Popülasyona dâhil işletmeler, arazi genişlikleri itibariyle homojen dağılım göstermediklerinden tabakalandırma yapılarak benzer işletmeler için homojen gruplar oluşturulmuştur. Araştırmanın örnek hacminin belirlenmesinde Neyman Yöntemi kullanılmıştır (Yamane, 2001). Örnek sayısı aşağıda verilen formül ile hesaplanmıştır.

$$
\mathrm{n}=\frac{\left(\Sigma N_{h} S_{h}\right)^{2}}{N^{2} D^{2} \sum N_{h} S_{h}^{2}}
$$

$\mathrm{n}$; örnek hacmini, $\mathrm{N}$; anakitledeki toplam birim sayısını, $\mathrm{Nh}$; h. tabakadaki birim sayısını, Sh; h. tabakanın standart sapmasını, D; d/Z; d; ortalamadan sapmayı, Z; t dağılım çizelgesindeki ( $\mathrm{N}-1)$ serbestlik derecesini ve belirli bir güven düzeyine (\%90, \%95, \%99 gibi) ait z dağılım değerini göstermektedir.

Araştırmada ortalamadan $\% 5$ sapma ve $\% 90$ güven düzeyine karşılık gelen $z \quad(z=1,65)$ değeri kullanılmıştır. Yukarıdaki formül kullanılarak 132 işletmenin örneklem çerçevesini oluşturduğu belirlenmiş (Çizelge 1 ve 2) ve bunların tabakalara dağıtımında ise aşağıdaki formülden yararlanılmıştır (Çiçek ve Erkan, 1996).

$$
n_{i}=\frac{N_{h} S_{h} n}{\sum\left(N_{h} S_{h}\right)}
$$


Çizelge 1. Örnekleme hacmi

Table 1. Sampling size

\begin{tabular}{ccccccc}
\hline Tabaka & Tabaka Sınırları (da) & Nh & Sh & Ortalama & $\begin{array}{c}\text { Toplam Örnek } \\
\text { Hacmi }\end{array}$ & $\begin{array}{c}\text { Tabaka Örnek } \\
\text { Sayısı }\end{array}$ \\
\hline I & $5-15,0$ & 2840 & 4,05 & 9,27 & & 38 \\
II & $15,1-50,0$ & 2132 & 8,89 & 28,05 & 132 & 62 \\
III & $50,1-+$ & 336 & 29,02 & 80,79 & & 32 \\
\hline Toplam & & & & & & 132 \\
\hline
\end{tabular}

Çizelge 2. Anket yapılan işletmelerin tabaka ve illere göre dağılımı Table 2. Distribution of farms surveyed by stratified and provinces

\begin{tabular}{|c|c|c|c|c|c|}
\hline \multirow{2}{*}{ il } & \multirow{2}{*}{ İlçe } & \multicolumn{3}{|c|}{ Tabakalara Göre Anket Sayıları } & \multirow{2}{*}{ Toplam } \\
\hline & & $\mathrm{I}$ & II & III & \\
\hline \multirow{3}{*}{ Isparta } & Eğirdir & 11 & 18 & 3 & 32 \\
\hline & Gelendost & 7 & 15 & 7 & 29 \\
\hline & Senirkent & 5 & 9 & 5 & 19 \\
\hline Karaman & Merkez & 15 & 20 & 17 & 52 \\
\hline Toplam & & 38 & 62 & 32 & 132 \\
\hline
\end{tabular}

Anaçlar, ağaç gelişimi, toprak koşullarına uyum, hastalık ve zararlılara karşı direnç, meyve verimi ve kalitesi üzerindeki olumlu etkiler için kullanılmaktadır (Castle ve ark., 2010). Üretim tekniği ve verimlilik, kullanılan anaca göre değişiklik göstermektedir. Anaçlar çeşitlerin büyümesini, erken verime yatmasını, verim ve meyve kalitesini, farklı toprak yapısına uyum kabiliyetini ve biyotik ve abiyotik stres koşullarına uyum gibi çeşitli faktörleri etkilemektedir (Jackson, 2003). Bu nedenle, üretim maliyetleri, işletmelerde üretimde kullanılan anaçlara göre hesaplanmış ve karşılaştırılmıştır. Karşılaştırmalar anket yapılan işletmelerde kullanılan anaçlara göre (Çöğür, M9, MM106 ve MM111) yapılmıştır. Kullanılan dört anaca her tabakada rastlanılmadığından tabakalar arasındaki farklılıklara bakılmamış ve anaçlar bazında iller karşılaştırılmıştır.

Üretim maliyetlerinin belirlenmesinde kısmi bütçe analizi yöntemi kullanılmıştır. Tüm maliyet unsurları dikkate alınmış ve üretim maliyetleri değişken ve sabit masraflar olarak ikiye ayrılmıştır. Aile işgücü ücret karşılığı yörede kadın ve erkek işçilere ödenen ortalama ücret dikkate alınarak belirlenmiştir. Genel idari giderler, değişken masrafların \%3'ü olarak alınmıştır. Döner sermaye faizi, değişken masraflara Ziraat Bankası'nın bitkisel üretim için uyguladığı faizin $(\% 4,5)$ yarısı uygulanarak hesaplanmıştır. Çıplak arazi değerinin faizi olarak çıplak arazi değerinin \%5'i alınmıştır (Kıral ve ark., 1999). Tesis masrafları yıllık amortisman payı, arazinin mevcut değeri ile çıplak değeri arasındaki farkın ekonomik ömre (25 yıl) bölünmesiyle hesap edilmiştir. Tesis sermayesi faizi ise toplam tesis masrafları yarı değerine \%5 faiz uygulanarak hesaplanmıştır. Brüt kar, gayrisafi üretim değerinden değişken masrafların çıkarılmasıyla, net kar gayrisafi üretim değerinden üretim masraflarının çıkarılmasıyla, nispi kar ise gayrisafi üretim değerinin üretim masraflarına bölünmesiyle bulunmuştur (Kıral ve ark.,1999).

\section{BULGULAR ve TARTIŞMA}

Incelenen işletmelerde, işletmeciler, elma yetiştiriciliğinin belli oranlarda gelir kaynağı olduğunu ve aile ihtiyaçlarını karşıladığını belirtmişlerdir. Elma yetiştiriciliğinin işletme gelirleri içindeki payı oldukça yüksektir. İşletmelerde elma yetiştiriciliği, Isparta ilinde $\% 63,8^{\prime}$ inin birincil gelir kaynağı iken, bu oran Karaman ilinde \%40,4'e düşmektedir. Genel olarak değerlendirildiğinde, işletmelerin yarısından fazlasının $(\% 54,6)$ birincil gelir kaynağının elma yetiştiriciliği olduğu belirlenmiştir (Çizelge 3).

Işletmelerde ortalama elma yetiştirilen alan Isparta ilinde 29,3 da iken, Karaman ilinde 43,86 da'dır. 2003 yılında Isparta/Eğirdir'de yapılan çalışmada ortalama elma alanı 8,03 da (Karamürsel ve ark., 2004), 2007 yılında Isparta ilinde yürütülen çalışmada 17,25 da (Bayav ve Armağan, 2008) bulunmuştur. Bu durum, Isparta ilinde işletmelerde yıllar bazında ortalama elma üretim alanının arttığını göstermektedir. Antalya ili Elmalı ilçesinde 2008 yılında yürütülen çalışmada ise ortalama elma üretim alanı (7,78 da), Isparta ve Karaman illerinden daha düşük olarak bulunmuştur (Aydoğmuş ve Yılmaz, 2010). 
Çizelge 3. İşletmelerde elma yetiştiriciliğinin işletme geliri içindeki payı (\%)

Table 3. The share of apple cultivation in the farm income (\%)

\begin{tabular}{lcccccccc}
\hline \multirow{2}{*}{ il } & \multicolumn{2}{c}{$<\% 25$} & \multicolumn{2}{c}{$\% 25-50$} & \multicolumn{2}{c}{$\% 50-75$} & \multicolumn{2}{c}{$>75$} \\
\cline { 2 - 10 } & Sayı & $\%$ & Sayı & $\%$ & Sayı & $\%$ & Sayı & $\%$ \\
\hline Isparta & 12 & 15,00 & 17 & 21,20 & 20 & 25,00 & 31 & 38,80 \\
Karaman & 17 & 32,70 & 14 & 26,90 & 4 & 7,70 & 17 & 32,70 \\
\hline Toplam & 29 & 22,00 & 31 & 23,40 & 24 & 18,20 & 48 & 36,40 \\
\hline
\end{tabular}

Isparta ilinde elma üretiminin büyük çoğunluğu çöğür anacıyla yapılmaktadır $(\% 61,1)$. Çöğür anacını sırasıyla MM111 (\%24,3), MM106 (\%12) ve M9 $(\% 2,6)$ klon anaçları takip etmektedir (Çizelge 4).

Karamürsel ve ark. (2004) tarafından yapılan çalışmada çöğür anaç kullanım oranı \%97,85 bulunmuştur. Bayav ve Armağan (2008) tarafından yapılan çalışmada ise sırasıyla çöğür \%87,00, M9 \%6,50, MM106 \%5,80 ve MM111 \%0,70 olarak hesaplanmıştır. Bu çalışma diğer çalışmalarla kıyaslandığında, çöğür anaç kullanım oranının bariz şekilde düştüğü ve kullanımın klon anaçlara doğru kaydığı görülmektedir. Birim alandan alınan ürün miktarını ve kalitesini artırmak adına üretimin klon anaçlar lehine kayması ümitvar olarak değerlendirilmektedir.

Isparta ilinde elma üretimi yapılan çeşitler; Golden Del. $(\% 37,9)$, Starkrimson Del. $(\% 20,5)$, Starking Del. $(\% 16,3)$,
Scarlet Spur (\%12,3), Granny Smith $(\% 2,3)$ ve diğer $(\% 10,6)$ çeşitlerdir (Çizelge 4). Karamürsel ve ark. (2004) tarafından yapılan çalışmada; \%54,6 Starking Del., \%37,5 Golden Del., \%5,1 Starkrimson Del. ve \%2,8 oranında diğer çeşitlerin yetiştirildiği bildirilmiştir. Bayav ve Armağan (2008) tarafından yapılan çalışmada ise Starking Del. \%47,1 ile en fazla yetiştirilen çeşit iken; Bu çeşidi \%29,8 ile Golden Del., \%12,1 ile Starkrimson Del. ve \%11 ile diğer çeşitler (Granny Smith, Braeburn, Fuji, Red Chief, Jersey Mac) takip etmiştir. Golden Del. çeşidinin yetiştirilme oranları yıllara göre büyük bir değişiklik göstermediği, buna karşın Starking Del. çeşidinin yetiştirilme oranının Starking Del. mutandı spur çeşitlere (Starkrimson Del., Scarlet Spur vb.) doğru kaydığı söylenebilir.

Çizelge 4. Isparta ilinde işletmelerde yetiştirilen anaç ve çeşitlerin dağılımı

Table 4. Distribution of rootstocks and varieties grown in farms in Isparta province

\begin{tabular}{|c|c|c|c|c|c|c|c|c|c|c|}
\hline \multirow[b]{2}{*}{ Çeşit/Anaç } & \multicolumn{2}{|c|}{ Çöğür } & \multicolumn{2}{|c|}{ M9 } & \multicolumn{2}{|c|}{ MM106 } & \multicolumn{2}{|c|}{ MM111 } & \multicolumn{2}{|c|}{ Çeşit Toplamı } \\
\hline & $\begin{array}{l}\text { Alan } \\
\text { (da) }\end{array}$ & $\%$ & $\begin{array}{l}\text { Alan } \\
\text { (da) }\end{array}$ & $\%$ & $\begin{array}{l}\text { Alan } \\
\text { (da) }\end{array}$ & $\%$ & $\begin{array}{l}\text { Alan } \\
\text { (da) }\end{array}$ & $\%$ & $\begin{array}{l}\text { Alan } \\
\text { (da) }\end{array}$ & $\%$ \\
\hline Golden Del. & 564,3 & 24,1 & 7,0 & 0,3 & 93,9 & 4,0 & 222,9 & 9,5 & 888,1 & 37,9 \\
\hline Granny Smith & 28,0 & 1,2 & 10,0 & 0,4 & 1,5 & 0,1 & 14,0 & 0,6 & 53,5 & 2,3 \\
\hline Scarlet Spur & 59,3 & 2,5 & 5,0 & 0,2 & 64,8 & 2,8 & 158,9 & 6,8 & 288,0 & 12,3 \\
\hline Starking Del. & 249,1 & 10,6 & 0,0 & 0,0 & 78,5 & 3,4 & 54,5 & 2,3 & 382,1 & 16,3 \\
\hline Starkrimson Del. & 415,1 & 17,7 & 0,0 & 0,0 & 4,5 & 0,2 & 61,0 & 2,6 & 480,6 & 20,5 \\
\hline Diğer* & 114,0 & 4,9 & 39,5 & 1,7 & 38,5 & 1,6 & 56,5 & 2,4 & 248,5 & 10,6 \\
\hline Anaç Toplamı & 1429,7 & 61,1 & 61,5 & 2,6 & 281,7 & 12,0 & 567,8 & 24,3 & 2340,7 & 100,0 \\
\hline
\end{tabular}

*Braeburn, Fuji, Gala, Jeromine, Pink Lady, Red Chief, Super Chief

Karaman ilinde işletmelerde anaç kullanımının, klon anaçlar lehine olduğu görülmüştür. Özellikle yoğun yetiştiricilikte kullanılan M9 anacının kullanım oranı, Isparta ili ile kıyaslandığında oldukça yüksektir. Karaman ilinde klon anaç kullanım oranı \%60,7 iken, Isparta ilinde bu oran \%38,9'dur.

Karaman ilinde yetiştirilen kırmızı elma çeşitlerden Starkrimson Del., Scarlet Spur ve Starking Del. \%54,7 yetiştirme oranıyla yarıdan fazlasını oluştururken; Golden Del. \%14,9, Granny Smith \% 9,8 ve diğer çeşitlerin (Braeburn, Fuji, Gala, Jeromine, Pink Lady, Red Chief) \%17,3 pay aldığı görülmektedir (Çizelge 5).

Araştırma kapsamında incelenen işletmelerde dekara düşen ağaç sayıları Çizelge $6^{\prime}$ da verilmiştir. Genel olarak değerlendirildiğinde Isparta ilinde dekara ortalama 51,7 adet ağaç ile üretim yapılırken, Karaman ilinde ise bu rakam 67,7 adete çıkmaktadır. Karaman ilinde dekara düşen ağaç sayısının yüksek olması klonal anaç kullanımının daha yaygın olmasından kaynaklanmaktadır. Elma anaçlarından M9 anacı hariç, 
diğer anaçlarda dekara ağaç sayısı Karaman ilinde daha fazladır. Karamürsel ve ark. (2004)'ın çalışmasında dekara 22,9 adet ağaç düştüğü, Bayav ve Armağan (2008)'ın çalışmasında ise 26,2 ağaç düştüğü tespit edilmiştir. Aydoğmuş ve Yılmaz'ın (2010) Antalya/Elmalı'da yapmış olduğu çalışmada; bodur anaçlı bahçelerde ortalama 180,5 ağaç, yarı bodur anaçlı bahçelerde 36,3 ağaç, çöğür anaçlı bahçelerde ise 25,3 ağaç ile üretim yapıldığı ortaya koyulmuştur. Çalışmalar arasındaki fark, her geçen yıl modern meyvecilik esaslarının dikkate alınarak, klonal anaçlarla sık dikim sistemlerinin kullanıldığı bahçelerin tesis edildiğini göstermektedir. Özellikle, Türkiye'nin iki önemli elma üretim bölgesinde bu gelişmelerin olması, elma yetiştiriciliğinde olumlu gelişmelerin olduğunu ortaya koymakta ve gelecek için hem üreticiler hem iç pazar hem de dış pazar açısından olumlu olarak değerlendirmektedir.

Çizelge 5. Karaman ilinde işletmelerde yetiştirilen anaç ve çeşitlerin dağııımı

Table 5. Distribution of rootstocks and varieties grown in farms in Karaman province

\begin{tabular}{|c|c|c|c|c|c|c|c|c|c|c|}
\hline \multirow[b]{2}{*}{ Çeşit/Anaç } & \multicolumn{2}{|c|}{ Çöğür } & \multicolumn{2}{|c|}{ M9 } & \multicolumn{2}{|c|}{ MM106 } & \multicolumn{2}{|c|}{ MM111 } & \multicolumn{2}{|c|}{ Çeşit Toplamı } \\
\hline & $\begin{array}{l}\text { Alan } \\
\text { (da) }\end{array}$ & $\%$ & $\begin{array}{l}\text { Alan } \\
\text { (da) }\end{array}$ & $\%$ & $\begin{array}{l}\text { Alan } \\
\text { (da) }\end{array}$ & $\%$ & $\begin{array}{l}\text { Alan } \\
\text { (da) }\end{array}$ & $\%$ & $\begin{array}{l}\text { Alan } \\
\text { (da) }\end{array}$ & $\%$ \\
\hline Golden Del. & 189,3 & 8,3 & 0,0 & 0,0 & 85,5 & 3,7 & 65,9 & 2,9 & 340,7 & 14,9 \\
\hline Granny Smith & 83,2 & 3,6 & 56,0 & 2,5 & 64,0 & 2,8 & 21,0 & 0,9 & 224,2 & 9,8 \\
\hline Scarlet Spur & 24,0 & 1,1 & 187,0 & 8,2 & 110,2 & 4,8 & 147,2 & 6,5 & 468,4 & 20,5 \\
\hline Starking Del. & 187,6 & 8,2 & 0,0 & 0,0 & 58,0 & 2,5 & 3,0 & 0,1 & 248,6 & 10,9 \\
\hline Starkrimson Del. & 410,2 & 18,0 & 0,0 & 0,0 & 94,7 & 4,2 & 98,7 & 4,3 & 603,6 & 26,5 \\
\hline Diğer* & 1,3 & 0,1 & 105,0 & 4,6 & 231,7 & 10,2 & 57,3 & 2,5 & 395,2 & 17,3 \\
\hline Anaç Toplamı & 895,5 & 39,3 & 348,0 & 15,3 & 644,0 & 28,2 & 393,1 & 17,2 & 2280,6 & 100,0 \\
\hline
\end{tabular}

*Braeburn, Fuji, Gala, Jeromine, Pink Lady, Red Chief

Çizelge 6. illere göre dekardaki ağaç sayısı

Table 6. Number of trees per decare by provinces

\begin{tabular}{lccccc}
\hline \multirow{2}{*}{ II/Anaç } & \multicolumn{5}{c}{ Ağaç Sayısı (Adet/da) } \\
\cline { 2 - 6 } & Çöğür & M9 & MM106 & MM111 & Genel \\
\hline Isparta & 35,3 & 204,4 & 85,4 & 63,5 & 51,7 \\
Karaman & 38,8 & 192,9 & 91,8 & 67,8 & 67,7 \\
\hline
\end{tabular}

İşletmelerde anaçlara göre işgücü ve çekigücü kullanım miktarları ve oranları çizelge 7 ve 8 'de verilmiştir. Çizelgeler incelendiğinde, her iki ilde de en fazla işgücü isteyen işlemler hasat ve budamadır. Seyreltme işlemi, işgücü kullanımı bakımından hasat ve budamadan sonra gelmektedir. Anaçlara göre işgücü kullanım miktarları birbirine yakın olmakla birlikte; Isparta ilinde MM106 anacı 125,5 saat/da, çöğür anacı 103,5 saat/da, MM111 anacı 101,8 saat/da ve M9 anacında 91,5 saat/da'dır. Karaman ilinde ise MM111 ve çöğür anacında 94 saat/da, MM106 anacında 93,4 saat/da ve M9 anacında 76,5 saat/da işgücü kullanılmıştır. Isparta ilinde en fazla işgücü kullanımı MM106 anaçlı bahçelerde iken, Karaman ilinde MM111 ve çöğür anaçlı bahçelerde olmuştur. Isparta'da yapılan çalışmada 103,61 saat/da (Demircan ve ark., 2005), Konya'da yapılan çalışmada yarı bodur anaçlı bahçelerde 95,14 saat/da ve bodur anaçlı bahçelerde 129,3 saat/da bulunmuştur (Kanat ve ark., 2017). Karamürsel ve ark. (2011) yapmış olduğu çalışmada İtalya, Fransa, Almanya ve ABD'de ortalama işgücü isteğinin 40-50 saat/da, Türkiye'de 103,6 saat/da olduğunu bildirmiştir (Bruille ve Barritt, 2005).

Çekigücünün büyük bir çoğunluğu ilaçlamada kullanılmaktadır. Isparta ve Karaman illerinde en fazla çekigücü kullanımı M9 anaçı bahçelerde olmuştur. Çekigücü kullanım miktarları işgücü kullanımında olduğu gibi Karaman ilinde daha düşüktür. Çekigücü ihtiyacı Isparta'da ortalama 13,1 saat/da ve Karaman'da 9,53 saat/da olarak hesaplanmıştır. Isparta'da yapılan çalışmada 5,6 saat/da (Demircan ve ark., 2005); Konya'da yapılan çalışmada yarı bodur anaçlarda 6,1 saat/da ve bodur anaçlarda 6,3 saat/da (Kanat ve ark., 2017), Antalya/Elmalı'da yapılan çalışmada ise 5,4 saat/da (Aydoğmuş ve Yılmaz, 2010) bulunmuştur (Çizelge 7 ve 8). 
Çizelge 7. Isparta ili elma üretiminde işgücü ve çekigücü kullanım miktarı ve oranları

Table 7. The amount of labour and machinery force and rates using in the production of apple in Isparta province

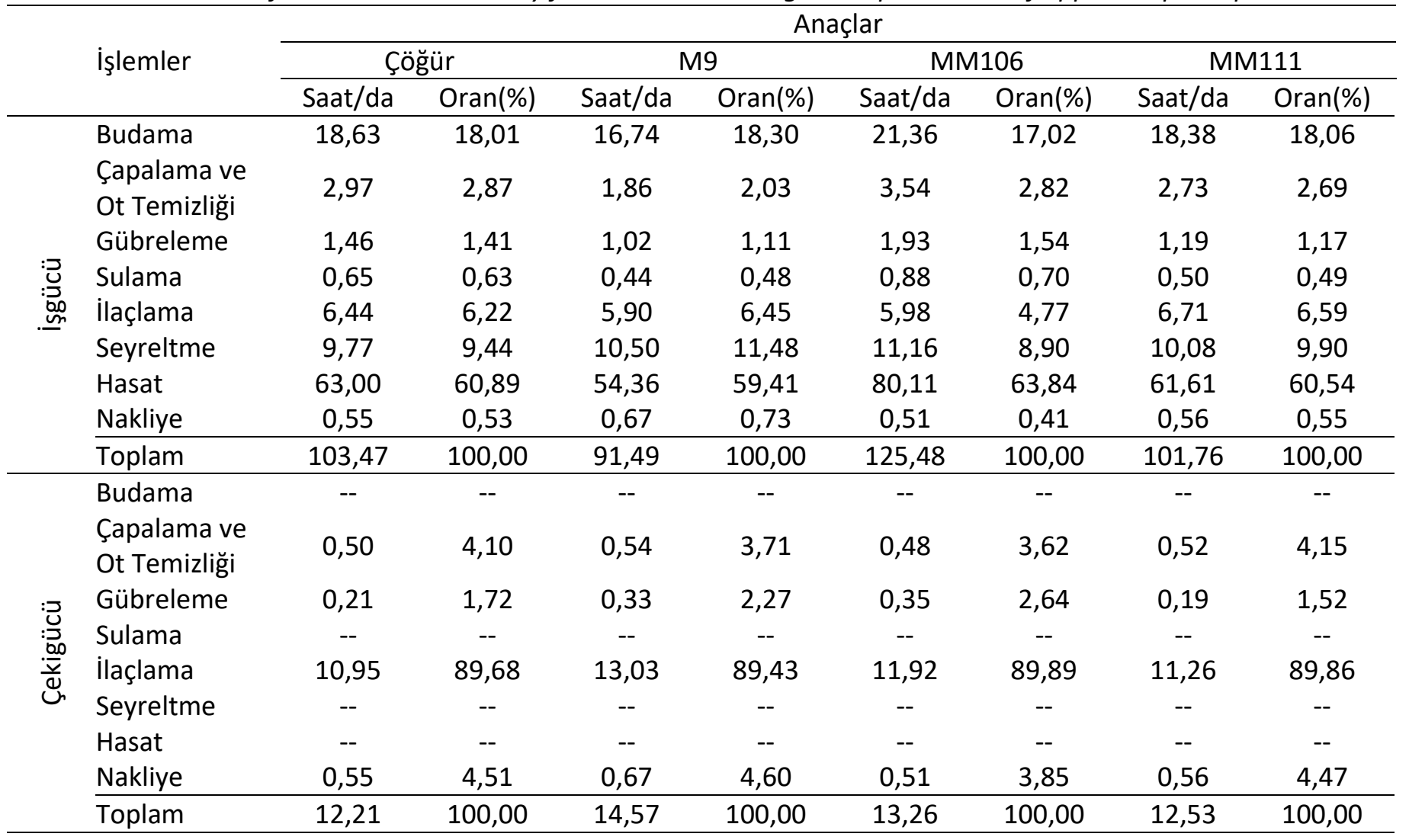

Çizelge 8. Karaman ili elma üretiminde işgücü ve çekigücü kullanım miktarı ve oranları

Table 8. The amount of labour and machinery force and rates using in the production of apple in Karaman province

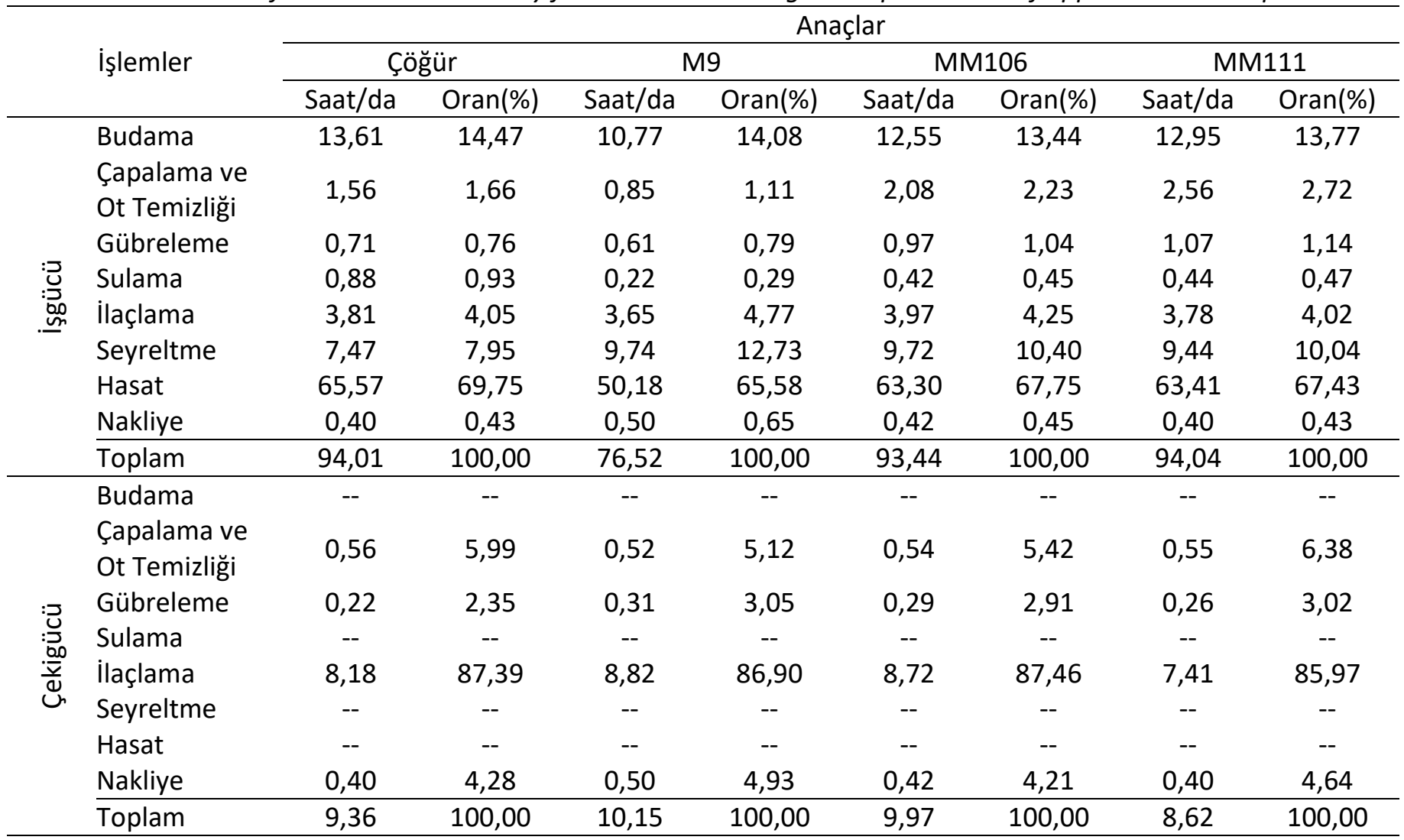


Isparta ilinde dekara üretim masrafı en fazla M9 anaçlı üretim plantasyonlarında gerçekleşmiş olup (4.583 TL/da), bunu sırasıyla; MM106 (3.889 TL/da), MM111 (3.874 TL/da) ve çöğür (3.840 TL/da) anaçlı üretim yapan işletmeler takip etmiştir. Üretim masraflarının toplamı içinde değişken-sabit masrafların oranı M9 anacında yaklaşık \%63-\%37 iken; MM106 anacında \%76-24, MM111 anacında \%73-\%27 ve çöğür anacında \%74-\%26 olduğu belirlenmiştir. Genel olarak değerlendirildiğinde, işletmeler ortalamasında üretim masrafları içinde değişken masrafların oranı yaklaşık \%71, sabit masrafların oranı ise \%29 olarak bulunmuştur. Tüm anaçlarda en önemli değişken masraf kalemleri sırasıyla ilaçlama, hasat, gübreleme ve budama olarak göze çarpmaktadır. Özellikle, Isparta ilinde yoğun ilaç kullanımı bunun en büyük nedeni olarak gösterilebilir. Nitekim araştırma kapsamında incelenen işletmelerde, bir üretim sezonunda ortalama 27,9 kez ilaçlama yapıldığı belirlenmiştir. Sabit masraflar içerisinde en önemli masraf unsuru çıplak arazi değerinin faizi olarak görülmektedir (Çizelge 9). Karamürsel ve ark. (2011) yapmış olduğu çalışmada üretim maliyetinin İtalya'da yaklaşık $1.509 € /$ da, Fransa'da $1.046 € /$ da, Almanya'da $998 € / d a, A B D \prime d e ~ 970 € / d a$, Şili'de $510 € / d a$, Polonya'da $357 € /$ da Çin'de $383 € /$ da ve Türkiye'de $384 € /$ da olduğunu bildirmiştir (Bruille ve Barritt, 2005). Isparta ilinde yapılan çalışmada üretim masrafları içinde değişken-sabit masrafların oranı \%73-\%27 (Demircan ve ark., 2005); Antalya ili Elmalı ilçesinde yapılan çalışmada bodur anaçlarda \%38-\%62, yarı bodur anaçlarda \%34\%66ve çöğür anaçlarda \%41-\%59 (Aydoğmuş ve Yılmaz, 2010); Konya ilinde yapılan çalışmada yarı bodur anaçlarda \%64-\%36, bodur anaçlarda ise \%65-\%35 bulunmuştur (Kanat ve ark., 2017). Isparta ve Konya illerinde yürütülen çalışmalarda, bu çalışmada olduğu gibi değişken masrafların oranı sabit masraflara göre daha yüksek bulunmuştur. Karamürsel ve ark. (2011) yapmış olduğu çalışmada değişken-sabit masrafların oranı İtalya'da yaklaşık \%45-\%55, Fransa'da \%52- \%48, ABD'de \%50-\%50, Şili'de \%55-\%45, Polonya'da \%37$\% 63$, Çin'de $\% 62-\% 38$ ve Türkiye'de \%49-51 olduğunu bildirmiştir (Bruille ve Barritt, 2005).

Çizelge 9. Isparta ili elma üretimi, üretim masrafları ve oranları

Table 9. Apple production, production costs and rates in the Isparta province

\begin{tabular}{lcccccc}
\hline \multirow{2}{*}{ Masraflar/Anaçlar } & Çögür & M9 & MM106 & MM111 & \multicolumn{2}{c}{ Genel } \\
\cline { 2 - 6 } & Masraf & Masraf & Masraf & Masraf & Masraf & Oran (\%) \\
& $($ TL/da) & $($ TL/da) & (TL/da) & (TL/da) & (TL/da) & \\
\hline Budama & 266,52 & 253,56 & 300,78 & 270,49 & 272,84 & 6,74 \\
Çapalama ve Ot Temizliği & 61,62 & 54,59 & 71,15 & 60,69 & 62,01 & 1,53 \\
Gübreleme & 298,75 & 444,76 & 370,68 & 274,81 & 347,25 & 8,58 \\
Sulama & 177,23 & 142,85 & 174,31 & 175,98 & 167,59 & 4,14 \\
İlaçlama & 976,10 & 911,06 & 861,14 & 921,06 & 917,34 & 22,67 \\
Meyve Seyreltme & 100,50 & 106,09 & 119,40 & 104,45 & 107,61 & 2,66 \\
Hasat & 703,50 & 592,70 & 757,37 & 717,02 & 692,65 & 17,12 \\
Nakliye & 110,63 & 154,15 & 115,48 & 167,14 & 136,85 & 3,38 \\
Ürün Sigortası & 67,73 & 145,60 & 102,95 & 81,41 & 99,42 & 2,46 \\
Döner Sermaye Faizi (\%4,5) & 62,16 & 63,12 & 64,65 & 62,39 & 63,08 & 1,56 \\
\hline Değişken Masraflar Toplamı & $2.824,73$ & $2.868,48$ & $2.937,92$ & $2.835,45$ & $2.866,65$ & 70,84 \\
\hline Genel Idari Giderler (\%3) & 84,74 & 86,05 & 88,14 & 85,06 & 86,00 & 2,13 \\
Çıplak Arazi Değerinin Faizi & 688,54 & 697,22 & 583,98 & 691,95 & 665,42 & 16,44 \\
Tesis Masrafları Amortisman Payı & 148,91 & 573,33 & 171,88 & 160,68 & 263,70 & 6,52 \\
Tesis Sermayesi Faizi & 93,07 & 358,33 & 107,42 & 100,42 & 164,81 & 4,07 \\
\hline Sabit Masraflar Toplamı & $1.015,26$ & $1.714,94$ & 951,42 & $1.038,11$ & $1.179,93$ & 29,16 \\
\hline Üretim Masrafları Toplamı & $3.839,99$ & $4.583,42$ & $3.889,34$ & $3.873,57$ & $4.046,58$ & 100,00 \\
\hline
\end{tabular}

Karaman ilinde tüm anaçlarda elma üretim masrafları Isparta'ya göre düşük bulunmuştur. İncelenen işletmelerde dekara üretim masrafı en fazla M9 anaçlı üretim alanlarında (3.538 TL/da) gerçekleşmiştir. Bunu sırasıyla; MM111 (3.439 TL/da), çöğür (3.318 TL/da) ve MM106 (3.153 TL/da) anaçlı üretim yapan işletmeler takip etmiştir. Üretim masraflarının toplamı içinde değişken-sabit masrafların oranı M9 anacında yaklaşık 
\%59-\%41 iken, MM111 anacında \%73-27, çöğür ve MM106 anacında \%75-\%25 olduğu belirlenmiştir. Genel olarak değerlendirildiğinde, işletmeler ortalamasında üretim masraflarının içinde değişken masrafların oranı yaklaşık \%70, sabit masrafların oranı ise \%30 bulunmuştur. Karaman ilinde de en önemli değişken masraf kalemleri, sırasıyla; ilaçlama, hasat, gübreleme ve budamadır. Sabit masraflar içinde ise çıplak arazi değerinin faizi en yüksek masraf unsuru olarak belirlenmiştir (Çizelge 10).

Çizelge 10. Karaman ili elma üretimi, üretim masrafları ve oranları

Table 10. Apple production, production costs and rates in the Karaman province

\begin{tabular}{lcccccc}
\hline \multirow{2}{*}{ Masraflar/Anaçlar } & Çögür & M9 & MM106 & MM111 & \multicolumn{2}{c}{ Genel } \\
\cline { 2 - 6 } & $\begin{array}{c}\text { Masraf } \\
\text { (TL/da) }\end{array}$ & $\begin{array}{c}\text { Masraf } \\
(\mathrm{TL} / \mathrm{da})\end{array}$ & $\begin{array}{c}\text { Masraf } \\
(\mathrm{TL} / \mathrm{da})\end{array}$ & $\begin{array}{c}\text { Masraf } \\
\text { (TL/da) }\end{array}$ & $\begin{array}{c}\text { Masraf } \\
\text { (TL/da) }\end{array}$ & Oran (\%) \\
\hline Budama & 250,53 & 192,71 & 227,75 & 233,64 & 226,16 & 6,73 \\
Çapalama ve Ot Temizliği & 49,03 & 38,05 & 58,13 & 64,69 & 52,47 & 1,56 \\
Gübreleme & 322,35 & 320,90 & 293,55 & 332,76 & 317,39 & 9,44 \\
Sulama & 260,06 & 178,27 & 232,49 & 259,17 & 232,50 & 6,92 \\
Ilaçlama & 680,37 & 595,42 & 723,62 & 567,34 & 641,68 & 19,09 \\
Meyve Seyreltme & 67,56 & 84,83 & 84,04 & 84,19 & 80,15 & 2,38 \\
Hasat & 576,71 & 408,83 & 544,89 & 597,49 & 531,98 & 15,82 \\
Nakliye & 98,33 & 120,48 & 94,00 & 122,69 & 108,88 & 3,24 \\
Ürün Sigortası & 123,09 & 117,39 & 64,94 & 181,64 & 121,76 & 3,62 \\
Döner Sermaye Faizi (\%4,5) & 54,63 & 46,28 & 52,28 & 54,98 & 52,04 & 1,55 \\
\hline Değişken Masraflar Toplamı & $2.482,65$ & $2.103,15$ & $2.375,68$ & $2.498,57$ & $2.365,01$ & 70,35 \\
\hline Genel Idari Giderler (\%3) & 74,48 & 63,09 & 71,27 & 74,96 & 70,95 & 2,11 \\
Çıplak Arazi Değerinin Faizi & 525,96 & 535,71 & 469,08 & 627,65 & 539,60 & 16,05 \\
Tesis Masrafları Amortisman Payı & 144,62 & 514,29 & 145,96 & 146,06 & 237,73 & 7,07 \\
Tesis Sermayesi Faizi & 90,38 & 321,43 & 91,23 & 91,29 & 148,58 & 4,42 \\
\hline Sabit Masraflar Toplamı & 835,44 & $1.434,52$ & 777,54 & 939,96 & 996,87 & 29,65 \\
\hline Üretim Masrafları Toplamı & $3.318,09$ & $3.537,68$ & $3.153,22$ & $3.438,53$ & $3.361,88$ & 100,00 \\
\hline
\end{tabular}

Her iki ilde de işletmelerde değişken masraf unsurları içinde materyal masrafları ve işgücü masraflarının tüm anaçlarda en yüksek masraf unsuru olduğu belirlenmiştir. Materyal masrafının yüksek olmasının nedeni ilaç ve gübre giderlerinin fazla olmasından kaynaklanmaktadır. Isparta ilinde materyal ve işgücü masraflarının toplam masraf içindeki payı \%36,6-\%28,2 iken, Karaman ilinde bu oran \%37,3-\%27,0 olarak hesaplanmıştır (Çizelge 11).
Demircan ve ark. (2005)'nın yapmış olduğu çalışmada materyal masraflarının toplam üretim masrafına oranı $\% 25,08$ iken, işgücü masrafları \%23,75 bulunmuştur. Yıllar içinde materyal ve işgücü masraflarının toplam üretim masrafı içindeki oranı artmıştır. Materyal masrafındaki artışın, yoğun ilaçlamadan ve buna bağlı olarak ilaç masrafının yüksek olmasından, işgücündeki artışın ise son yıllarda işgücü ücretlerinde yaşanan artıştan kaynaklandığı düşünülmektedir. 
Çizelge 11. Isparta ve Karaman illeri elma üretiminde işgücü, çekigücü ve materyal masrafları Table 11. Labour force, machinery force and material costs in the apple production in the Isparta and Karaman provinces

\begin{tabular}{|c|c|c|c|c|c|c|c|c|c|c|}
\hline \multirow[t]{2}{*}{ Anaç } & \multirow[t]{2}{*}{ il } & \multicolumn{2}{|c|}{ İ̧̇gücü } & \multicolumn{2}{|c|}{ Çekigücü } & \multicolumn{2}{|c|}{ Materyal } & \multirow{2}{*}{$\begin{array}{c}\begin{array}{c}\text { Toplam } \\
\text { Değişken } \\
\text { Masraflar }\end{array} \\
\text { TL/da }\end{array}$} & \multirow{2}{*}{$\begin{array}{c}\text { Toplam Sabit } \\
\text { Masraflar } \\
\text { TL/da }\end{array}$} & \multirow{2}{*}{$\begin{array}{c}\text { Toplam } \\
\text { Üretim } \\
\text { Maliyeti } \\
\text { TL/da }\end{array}$} \\
\hline & & TL/da & $\%$ & TL/da & $\%$ & TL/da & $\%$ & & & \\
\hline \multirow{2}{*}{ Çöğür } & Isparta & $1.131,2$ & 29,5 & 169,1 & 4,4 & $1.462,2$ & 38,1 & $2.824,7$ & $1.015,3$ & $3.840,0$ \\
\hline & Karaman & 963,3 & 29,0 & 141,1 & 4,3 & $1.323,6$ & 39,9 & $2.482,7$ & 835,4 & $3.318,1$ \\
\hline \multirow{2}{*}{ M9 } & Isparta & $1.001,8$ & 21,9 & 223,9 & 4,9 & $1.579,7$ & 34,5 & $2.868,5$ & $1.714,9$ & $4.583,4$ \\
\hline & Karaman & 746,5 & 21,1 & 151,0 & 4,3 & $1.159,4$ & 32,8 & $2.103,2$ & $1.434,5$ & $3.537,7$ \\
\hline \multirow{2}{*}{ MM106 } & Isparta & $1.292,1$ & 33,2 & 160,8 & 4,1 & $1.420,4$ & 36,5 & $2.937,9$ & 951,4 & $3.889,3$ \\
\hline & Karaman & 949,4 & 30,1 & 159 & 5,0 & $1.215,1$ & 38,5 & $2.375,7$ & 777,5 & $3.153,2$ \\
\hline \multirow{2}{*}{ MM111 } & Isparta & $1.144,9$ & 29,6 & 169,4 & 4,4 & $1.458,8$ & 37,7 & $2.937,9$ & $1.038,1$ & $3.873,6$ \\
\hline & Karaman & 977,4 & 28,4 & 150,3 & 4,4 & $1.315,9$ & 38,3 & $2.498,6$ & 940,0 & $3.438,5$ \\
\hline \multirow{2}{*}{ Genel } & Isparta & $1.142,5$ & 28,2 & 180,8 & 4,5 & $1.480,3$ & 36,6 & $2.866,7$ & $1.179,9$ & $4.046,6$ \\
\hline & Karaman & 909,2 & 27,0 & 150,4 & 4,5 & $1.253,5$ & 37,3 & $2.365,0$ & 996,9 & $3.361,9$ \\
\hline
\end{tabular}

Isparta ili elma işletmelerinde dekara brüt kar en yüksek M9 anacından elde edilirken; MM106, MM111 ve çöğür anaçlarından elde edilen brüt kar değerleri birbirine çok yakın bulunmuştur. Nispi kar sıralaması da aynı şekildedir. Nispi kar M9 anacında 1,99, MM106 ve MM111 anacında 1.75 , çöğür anacında ise 1,74 olarak bulunmuştur. Genel olarak değerlendirildiğinde işletmelerde 1,80 olan oransal kar 1 TL'lik masrafa karlılık 1,80 TL gelir elde edildiğini göstermektedir (Çizelge 12). Demircan ve ark. (2005)'nın yapmış olduğu çalışmada nispi kar 1,63 olarak bulunmuştur.

Çizelge 12. Isparta ili karlılık durumu

Table 12. Profitability in the Isparta province

\begin{tabular}{lccccc}
\hline \multirow{2}{*}{ Ekonomik Göstergeler } & \multicolumn{5}{c}{ Anaçlar } \\
\cline { 2 - 6 } & Çöğür & M9 & MM106 & MM111 & Genel \\
\hline Verim (ton/da) & 5,60 & 6,62 & 5,93 & 5,48 & 5,91 \\
Elma Üretim Maliyeti (TL/kg) & 0,69 & 0,69 & 0,66 & 0,71 & 0,69 \\
Ortalama Elma Satış Fiyatı (TL/kg) & 1,19 & 1,38 & 1,15 & 1,23 & 1,24 \\
Gayrisafi Üretim Değeri (TL/da) & $6.663,94$ & $9.107,62$ & $6.797,21$ & $6.759,40$ & $7.303,74$ \\
Brüt Kar (TL/da) & $3.839,20$ & $6.239,14$ & $3.859,29$ & $3.923,94$ & $4.437,10$ \\
Net Kar (TL/da) & $2.823,94$ & $4.524,20$ & $2.907,87$ & $2.885,83$ & $3.257,16$ \\
Nispi Kar & 1,74 & 1,99 & 1,75 & 1,75 & 1,80 \\
\hline
\end{tabular}

Karaman ilinde de $\mathrm{M} 9$ anacı ile üretim yapan işletmelerde en yüksek nispi kar elde edilmiştir. M9 anacını MM111, çöğür ve MM106 anaçları takip etmiştir. Karaman ilindeki elma işletmelerindeki nispi kar değeri, Isparta iline göre düşük bulunmuştur. Karaman ilinde düşük masraflara rağmen, nispi karın düşük olması; verim düşüklüğünden kaynaklanmıştır. Isparta ilinde $1 \mathrm{~kg}$ elma 0,69 TL'ye mal edilirken; Karaman ilinde, 0,80 TL'ye mal edilmiştir. Satış fiyatında da bölgesel farklııklar olduğu tespit edilmiştir. $1 \mathrm{~kg}$ elma Isparta ilinde ortalama 1,24 TL'ye satılırken, Karaman ilinde 1,13 TL'ye satılmaktadır (Çizelge 13). Tüm bu ekonomik göstergeler dikkate alındığında, Isparta ilindeki elma işletmeleri, Karaman ilindeki işletmelere göre daha karlı durumdadır.
Elma, Türkiye için önemli meyvelerden biridir ve ekonomide önemli bir yer tutmaktadır. Özellikle tüm gelir gruplarına hitap eden özelliği, önemini daha da artırmaktadır. Türkiye'de önemli elma üretim merkezlerinden olan Isparta ve Karaman illeri için elma üretimi, büyük bir istihdam kaynağıdır.

Bu çalışmada Isparta ve Karaman illeri elma üretim maliyeti, üreticilerden alınan verilerle, anaçlar bazında hesaplanmış ve karşılaştııılmıştır. Yapılan hesaplamalar elma üretiminin her iki ilde de karlı birer yatırım olduğunu göstermektedir. Ancak üretim maliyetleri içinde materyal ve işgücü masraflarının yüksekliği bu karlılığı düşük seviyelerde tutmaktadır. Özellikle yoğun ilaçlama yapılması en önemli sorun olarak tespit 
edilmiştir. Bunun için yayım faaliyetleri ile çiftçiler eğitilmeli ve bilinçlendirilmelidir. Isparta ilinde ortalama üretim maliyeti $0,69 \mathrm{TL} / \mathrm{kg}$, Karaman ilinde 0,80 $\mathrm{TL} / \mathrm{kg}^{\prime} \mathrm{d} ı \mathrm{r}$

Çizelge 13. Karaman ili karlılık durumu

Table 13. Profitability in the Karaman province

\begin{tabular}{lccccc}
\hline \multirow{2}{*}{ Ekonomik Göstergeler } & \multicolumn{5}{c}{ Anaçlar } \\
\cline { 2 - 6 } & Çöğür & M9 & MM106 & MM111 & Genel \\
\hline Verim (ton/da) & 3,97 & 4,53 & 4,16 & 4,18 & 4,21 \\
Elma Üretim Maliyeti (TL/kg) & 0,83 & 0,78 & 0,76 & 0,82 & 0,80 \\
Ortalama Elma Satış Fiyatı (TL/kg) & 1,07 & 1,36 & 0,97 & 1,13 & 1,13 \\
Gayrisafi Üretim Değeri (TL/da) & $4.262,63$ & $6.175,43$ & $4.053,80$ & $4.702,47$ & $4.774,47$ \\
Brüt Kar (TL/da) & $1.779,99$ & $4.072,27$ & $1.678,12$ & $2.203,90$ & $2.409,46$ \\
Net Kar (TL/da) & 944,55 & $2.637,75$ & 900,57 & $1.263,94$ & $1.412,59$ \\
Nispi Kar & 1,28 & 1,75 & 1,29 & 1,37 & 1,42 \\
\hline
\end{tabular}

Isparta ili elma üretimi Karaman iline göre daha karlı bulunmuştur. Isparta'da 3.257 TL/da net kar elde edilirken, Karaman'da $1.412 \quad \mathrm{TL} / \mathrm{da}$ olarak gerçekleşmiştir. Bunun en büyük nedeni, Karaman'da birim alandan alınan verimin düşüklüğüdür. Isparta ilinde ortalama $5.910 \mathrm{~kg} / \mathrm{da}$ ürün elde edilmesine rağmen, Karaman ilinde $4.210 \mathrm{~kg} / \mathrm{da}$ ürün alınmıştır. Bu olumsuz duruma çözüm bulunabilmesi için yetiştiricilik sorunlarının uzman bir ekip tarafından tespit edilerek çözüm önerileri geliştirilmelidir.

Isparta ve Karaman illerinde klonal anaçla (M9, MM106, MM111) üretim yapan işletmelerde verimlilik, çöğür anaçla üretim yapanlara göre daha yüksek bulunmuştur. Özellikle tam bodur anaç olarak nitelendirilen M9 anacı, verimlilikte en yüksek değeri almıştır. Ancak M9 anacı, bahçe tesisinde destek sistemine intiyaç duyması nedeniyle tesis masrafları daha yüksektir. Üreticilerin M9 anacıyla üretimini sınırlayan en büyük engellerden biri, bahçe tesis masraflarının yüksek olmasıdır. Bu nedenle yeni elma bahçesi tesislerinde, tam bodur sistemde üretim yapmayı düşünen üreticilere, tesis masraflarında destek sağlanması, Türkiye'nin elma üretimindeki konumunu daha da güçlendirecektir. Ayrıca üreticilerin pazar talepleri doğrultusunda yeni çeşitlerle bahçe tesis etmesi teşvik edilmelidir.

\section{ÖZET}

Amaç: Bu çalışmada, Türkiye elma üretiminin $\% 20,2^{\prime}$ sini karşılayan Isparta ve \%13,4'ünü karşılayan Karaman illerinin üretim maliyetleri karşılaştırılmıştır.

Yöntem ve Bulgular: Tabakalı tesadüfi örnekleme yöntemine göre 132 elma işletmesi belirlenmiş ve işletmeciler ile yüz yüze görüşülmüştür. İşletme verileri, 2017-2018 üretim sezonuna aittir. Üretim maliyetleri, üretim yapılan bahçede kullanılan anaçlara göre hesaplanmıştır. Dekara üretim masrafı Isparta ilinde ortalama 4.047 TL, Karaman ilinde ise 3.362 TL olarak belirlenmiştir. Nispi kar, Isparta ilinde 1,80 ve Karaman ilinde 1,42 olarak bulunmuştur. Her iki ilde de M9 anacıyla tesis edilen bahçelerde en yüksek kar oranı elde edilmiştir. En önemli masraf kalemi materyal masraflarıdır. İlaçlama masraflarının, Isparta ilinde $\% 22,7$ ve Karaman ilinde $\% 19,1^{\prime}$ lik pay ile üretim masrafları içinde en yüksek girdi olduğu belirlenmiştir.

Genel Yorum: Yapılan hesaplamalar elma üretiminin her iki ilde de karlı birer yatırım olduğunu göstermektedir. Ancak üretim maliyetleri içinde materyal ve işçilik masraflarının yüksekliği, bu karlılığı düşük seviyelerde tutmaktadır.

Çalışmanın Önemi ve Etkisi: Elma üretiminin teknik yönleri birçok çalışmada ele alınmasına rağmen, ekonomik yönden değerlendirilmesine ilişkin yapılan çalışmalar çok fazla değildir. Bu çalışma, Türkiye üretiminde önemli bir yere sahip olan illerde (Isparta ve Karaman) gerçekleştirilmiş ve elma üretiminin ekonomik yönü ortaya koyulmuştur.

Anahtar Kelimeler: Elma, Tek ürün bütçe analizi, Üretim maliyeti, Isparta, Karaman

\section{TEŞEKKÜR}

Bu makale doktora çalışmasının bir bölümüdür.

\section{ÇIKAR ÇATIŞMA BEYANI}

Yazar(lar) çalışma konusunda çıkar çatışmasının olmadığını beyan eder.

\section{ARAŞTIRMACILARIN KATKI ORANI BEYANI}

Yazarlar çalışmaya eşit oranda katkı sağlamış olduklarını beyan eder. 


\section{KAYNAKLAR}

Akcay Y, Akay M, Uzunöz M (1999) Tokat Merkez Illçede Yetiştirilen Şeftali, Elma ve Vişnenin Üretim Maliyeti ve Karlılığının Belirlenmesi Üzerine Bir Araştırma. Gaziosmanpaşa Üniversitesi Ziraat Fakültesi Dergisi, 16(1):85-98.

Anonim (2020a) Food and Agriculture Organization of the United Nations. http://www.fao.org/faostat/en/\#data (Erişim Tarihi: 20 Ocak 2020).

Anonim (2020b) Türkiye İstatistik Kurumu. https://biruni.tuik.gov.tr/medas/?kn=92\&locale=tr (Erişim Tarihi: 20 Ocak 2020).

Aydoğmuş F, Yılmaz i (2010) Antalya ilinde bodur, yarı bodur ve çöğür anaç kullanılarak yapılan elma üretiminin ekonomik analizi. Akdeniz Üniversitesi Ziraat Fakültesi Dergisi, 23: 127-135.

Badiu D, Arion FH, Muresan IC, Lile R, Mitre V (2015) Evaluation of Economic Efficiency of Apple Orchard Investments. Sustainability, 7:10521-10533.

Bayav A, Armağan G (2008) Isparta illinde elma işletmelerinde yeniliklerin ve araştırma sonuçlarının benimsenme düzeyleri ve etki değerlendirmeleri. VIII. Ulusal Tarım Ekonomisi Kongresi, 25-27 Haziran, Bursa, 168-181.

Bayramoğlu Z, Çelik Y, Oğuz C (2009) Konya Illinde Elma Üretiminin Mevcut Durumu ve Gelişme Olanakları. Tarım Bilimleri Araştırma Dergisi, 2 (1):11-15.

Bruille JD, Barritt BH (2005) Global Apple Study-A Comparison of Production Practices and Costs of Production in Leading Apple Producing Countries. 48th Annual Conference (International Dwarf Fruit Tree Association), 5-9 February, USA.

Castle WS, Baldwin JC, Muraro RP, Littell R (2010) Performance of 'Valencia' sweet orange trees on 12 rootstocks at two locations and an economic interpretation as a basis for rootstock selection. Hortscience, 45, 523-533.

Çiçek A, Erkan O (1996) Tarım Ekonomisinde Araştırma ve Örnekleme Yöntemleri G.O.P.Üniversitesi Ziraat Fakültesi Yayınları No:12, Ders Notları Serisi No:6, Tokat.

Demircan V, Yılmaz H, Binici T (2005) Isparta ilinde elma üretim maliyeti ve gelirinin belirlenmesi. Tarım Ekonomisi Dergisi, 11(2): 71-80.

Ergün ME, Osmanlıoğlu E, Erkal S, Şafak A, Gençtürk S, Yakut Y, Kaya A (1984) Üretimin yoğun olduğu yörelerde elma üretimi, değerlendirilmesi, maliyeti ile pazarlama sorunları üzerine araştırma. Atatürk Merkez Bahçe Kültürleri Araştırma Enstitüsü Yayınları, Yalova.
Glover J, Hinman H, Reganold J, Andrews P (2002) A cost of production analysis of conventional vs. integrated vs. organic apple production systems. Agricultural Research Publication XB1041, Washington State University, Yakima, Washington, USA. 68 p.

Gül M, Erkan O (2005) Toros Dağları geçit bölgelerinde elma üretiminin ekonomik analizi. Çukurova Üniversitesi Ziraat Fakültesi Dergisi, 20(4):87-96.

Jackson JE (2003) Biology of Apples and Pears. Cambridge University Press. ISBN, 0521380189, United Kingdom, p:141-157.

Kanat Z, Çelik Y, Çay Ş (2017) Konya ilinde Bodur ve Yarı Bodur Elma Üretiminin Maliyet Analizi. Selçuk Tarım ve Gıda Bilimleri Dergisi, 31(1), p 56-62.

Karamürsel $D$, Öztürk FP, Öztürk $G$, Kaymak $S$, Eren $i$, Akgül H (2004) Eğirdir Yöresi Elma Yetiştiriciliğinin Durumu ve Sorunlarının Belirlenmesi ille Ekonomik Yönden Değerlendirilmesi. Türkiye VI. Tarım Ekonomisi Kongresi, 16-18 Eylül, Tokat, 225-231.

Karamürsel D, Öztürk FP, Emre M (2011) Global Elma Endüstrisi ve Üretim Ekonomisi. Elma Kültürü (Eds. Akgül H, Kaçal E, Öztürk FP, Özongun Ş, Atasay A, Öztürk G) Eğirdir Bahçe Kültürleri Araştırma Enstitüsü Yayınları, Yayın No:37, ISBN: 978-975-407-307-2, Isparta, 461-482.

Kıral T, Kasnakoğlu H, Tatlıdil F, Fidan H, Gündoğmuş E (1999) Tarımsal Ürünler için Maliyet Hesaplama Metodolojisi ve Veri Tabanı Rehberi. Tarımsal Ekonomi Araştırma Enstitüsü Proje Raporu, Yayın No:37, ISBN 975-407-051-2, Ankara.

Malik ZA (2013) Assesment of apple production and marketing problems in Kashmir Valley. Journal of Economic \& Social Development, 9(1):152-156.

Oğuz C (1997) Karaman ilinde elma üretim işletmelerinin ekonomik analizi. Türkiye Yumuşak Çekirdekli Meyveler Sempozyumu, 2-5 Eylül, Yalova, 305-312.

Piyush M, Kumar TR, Sachin C (2013) Production and marketing of apple fruit crop- a study Premiseto Shimla District of Himachal Pradesh, India. International Journal of Bio-Resource and Stress Management, 4(4):610-613.

Robinson T, Hoying S, Sazo MM, DeMarree A, Dominguez $L$ (2013) A vision for apple orchard systems of the future. New York Fruit Quarterly, 21(3):11-16.

Uçar K, Palkovic J, Engindeniz S (2016) Apple Investment in Europe: A Case Study for Slovakia. 27th International Scientific-Expert Congress of Agriculture and Food Industry, 26-28 September 2016, Bursa-Turkey, pp:152-157. 
Uzunöz M, Akçay Y (2006) A Profitability Analysis of Investment of Peach and Apple Growing in Turkey. Journal of Agriculture and Rural Development in the Tropics and Subtropics (JARTS), 107(1); 11-18.

Yamane T (2001) Temel Örnekleme Yöntemleri. Çevirenler: Alptekin Esin, Celal Aydın, M. Akif Bakır, Esen Gürbüzsel, Literatür Yayıncılık, İstanbul.
Wani F (2017) Production and Marketing of Apple in Himachal Pradesh:An Empirical Study. International Journal Of Research Culture Society, 1(10):34-40.

Zbanca A, Negritu G (2013) Feasibility of investments for planting and maintenance of apple orchards by applying various technologies. Economic Engineering in Agriculture and Rural Development, 13(1):465469. 